\title{
Microbial bioremediation of heavy metals
}

\author{
Amanso Tayang and L. S. Songachan* \\ Department of Botany, Banaras Hindu University, Varanasi 221 005, India
}

Heavy metals are persistent in nature and toxic to all life forms. Increase in industrialization, urbanization and unsafe agriculture practices is constantly adding heavy metals to the environment, and consequently causing heavy metal pollution of water and soil. Considering the negative impacts of heavy metals on the environment, several strategies have been devised to remediate them. However, most of these have their own limitations. Bioremediation of metals by microorganisms is efficient, cost-effective and environmentfriendly method of metal detoxification. Microbes can utilize metal contaminants as their energy source and transform them to less toxic forms. When exposed to metals for a considerable period of time, microorganisms interact with them and become tolerant by developing resistance mechanism against them. Metalmicrobe interactions can occur in several ways such as biosorption, bioleaching, biomineralization, bioaccumulation and biotransformation. Study of these interactions is important to understand resistance mechanisms against metals which include barriers, efflux system, sequestration and reduction of metals. These mechanisms are encoded by the resistance genes localized in chromosomes and plasmids. Understanding resistance mechanisms against metals in microorganisms becomes crucial for devising strategies for bioremediation of metals.

Keywords: Bioremediation, heavy metals, microorganisms, metal-microbe interactions, resistance mechanisms.

HUMAN activities such as industrialization, urbanization, advancement in technology, and unsafe agriculture practices have increased pollution at an alarming rate and degraded the environment ${ }^{1}$. The resultant degradation of the environment with toxic chemicals and hazardous heavy metals has led to contamination of soil, surface water and groundwater, and is immediately a major threat to all life forms on earth ${ }^{2,3}$. Heavy metals are toxic and cannot be degraded through biological, chemical or physical means to harmless by-products. Therefore, unlike organics, their longevity in the environment can be substantial and can only be transformed to less toxic forms ${ }^{3-5}$. They enter into our body through the food chain. As our body cannot metabolize them, they get accumulated, and become cytotoxic and mutagenic ${ }^{5,6}$. In humans, heavy metal toxicity can cause cancer, cardiovascular and neurological diseases, liver damage as well as central nervous system and sen-

*For correspondence. (e-mail: rayskybl@yahoo.co.in) sory disturbances ${ }^{3}$. In plants, heavy metals can cause chlorosis, reduced seed germination and reduced growth because of decreased rate of photosynthesis, mineral nutrition and reduced enzyme activities ${ }^{7,8}$. Besides, heavy metal toxicity also increases reactive oxygen species (ROS) production, which includes oxygen radicals and non-radical derivates of molecular oxygen. Enhanced ROS production decreases antioxidant molecules and can lead to cell death by affecting the normal functioning of the organism ${ }^{9-11}$. Metal toxicity can also be a serious threat to microorganisms. It causes protein and nucleic acid denaturation, inhibition of enzyme activities, disruption of cell membrane and cellular functions, oxidative stress, chromosomal aberrations, mutation, etc. in them ${ }^{11-13}$. Consequently, considering the negative impacts of metal toxicity, immediate actions are needed to address detoxification of heavy metals.

There are several methods used to remove heavy metal from contaminated sites. The most widely used techniques include metal precipitation, filtration, ion-exchange resin and reverse osmosis. Metal precipitation has been proved to be cost-effective and easy to use ${ }^{14}$. However, it may cause secondary environmental issues ${ }^{15}$. Other mentioned techniques proved to be environmentally friendly, but expensive and relatively inefficient in removing heavy metals, and also organic contaminants ${ }^{16,17}$. To solve these problems, bioremediation is an important, attractive, costeffective and environment-friendly method as this technique utilizes microorganisms which are naturally available in contaminated sites and can readily assist in the removal of heavy metals ${ }^{3}$. Use of microorganisms like algae, bacteria and fungi to detoxify heavy metals in the contaminated sites has emerged as a promising tool (Table 1). Considering microorganisms for bioremediation can be attributed to certain bacterial characteristics. Microorganisms are ubiquitous; they are minute and multiply rapidly, and increase in huge numbers when inoculated to contaminated sites ${ }^{18}$. When they are continuously exposed to pollutants, they become tolerant and exhibit exceptional levels of capability to transform pollutants as their source of energy and raw material. They can also genetically adapt to degrade the contaminants. These attributes can be exploited to make microorganisms an ideal candidate for a low-cost and more environmentfriendly biological process ${ }^{19}$. Besides, they are nature's original recyclers.

This article highlights the studies carried out in the last 20 years in the field of heavy metal bioremediation. It 
Table 1. Heavy metal resistant microorganisms as potential tools for bioremediation

\begin{tabular}{|c|c|c|c|}
\hline Bacteria & $\begin{array}{l}\text { Heavy metals } \\
\text { studied }\end{array}$ & $\begin{array}{l}\text { Removal of } \\
\text { heavy metals }\end{array}$ & Reference \\
\hline Acinetobacter junii & $\mathrm{Pb}(\mathrm{II})$ & $1071 \mathrm{mg} \mathrm{g}^{-1}$ & 81 \\
\hline Arthrobacter viscosus & $\mathrm{Cr}(\mathrm{IV})$ & $1161 \mathrm{mg} \mathrm{g}^{-1}$ & 142 \\
\hline \multirow[t]{3}{*}{ Geobacillus thermodenitrificans } & $\mathrm{Cu}(\mathrm{II})$ & $57 \mathrm{mg} \mathrm{g}^{-1}$ & 143 \\
\hline & $\mathrm{Pb}(\mathrm{II})$ & $53 \mathrm{mg} \mathrm{g}^{-1}$ & \\
\hline & $\mathrm{Zn}(\mathrm{II})$ & $18 \mathrm{mg} \mathrm{g}^{-1}$ & \\
\hline Bacillus sp. & $\mathrm{Cu}(\mathrm{II})$ & $44.73 \%$ & 144 \\
\hline Bacillus thuringiensis & $\mathrm{Cd}(\mathrm{II})$ & $97.67 \%$ & 145 \\
\hline Bacterial mixtures & & & 146 \\
\hline (Sporosarcina soli $\mathrm{B}-22$, & $\mathrm{Cu}(\mathrm{II})$ & $5.6 \%$ & \\
\hline Viridibacillus arenosi B-21 and & $\mathrm{Cd}(\mathrm{II})$ & $85.4 \%$ & \\
\hline Enterobacter cloacae KJ-47 and E. cloacae KJ-46) & $\operatorname{Pd}(\mathrm{II})$ & $98.6 \%$ & \\
\hline Turbinaria vulgaris & $\mathrm{Cr}(\mathrm{VI})$ & $90.08 \%$ & 147 \\
\hline Ochrobactrum sp. & $\mathrm{Cd}(\mathrm{II})$ & $83.3 \mathrm{mg} \mathrm{g}^{-1}$ & 148 \\
\hline \multirow[t]{2}{*}{ P. aeruginosa } & $\mathrm{Hg}(\mathrm{II})$ & $180 \mathrm{mg} \mathrm{g}^{-1}$ & 149 \\
\hline & $\mathrm{Pb}(\mathrm{II})$ & $98 \%$ & 150 \\
\hline \multirow[t]{6}{*}{ Pseudomonas sp. } & $\mathrm{Cu}(\mathrm{II})$ & $70.4 \%$ & 151 \\
\hline & $\mathrm{Cd}(\mathrm{II})$ & $93.5 \%$ & \\
\hline & $\mathrm{Pb}(\mathrm{II})$ & $97.8 \%$ & \\
\hline & As(III) & $34 \%$ & 152 \\
\hline & $\mathrm{Cd}(\mathrm{II})$ & $55 \%$ & \\
\hline & $\mathrm{Co}(\mathrm{II})$ & $53 \%$ & \\
\hline Rhodobacter capsulatus & $\mathrm{Zn}(\mathrm{II})$ & $164 \mathrm{mg} \mathrm{g}^{-1}$ & 153 \\
\hline \multirow[t]{3}{*}{ Sporosarcina pasteurii } & $\mathrm{Pb}(\mathrm{II})$ & $98.71 \%$ & 154 \\
\hline & $\mathrm{Cd}(\mathrm{II})$ & $97.15 \%$ & \\
\hline & $\mathrm{Zn}(\mathrm{II})$ & $94.83 \%$ & \\
\hline \multirow[t]{3}{*}{ Bacillus licheniformis } & $\mathrm{Cu}(\mathrm{II})$ & $32 \%$ & 155 \\
\hline & $\mathrm{Cr}(\mathrm{VI})$ & $95 \%$ & \\
\hline & $\mathrm{Fe}(\mathrm{II})$ & $52 \%$ & \\
\hline \multirow[t]{2}{*}{ Staphylococcus sp. } & $\mathrm{Cd}(\mathrm{II})$ & $44 \%$ & 156 \\
\hline & $\mathrm{Cu}(\mathrm{II})$ & $34 \%$ & \\
\hline Stenotropho monasmaltophilia & $\mathrm{Cu}(\mathrm{II})$ & $94 \%$ & 157 \\
\hline \multirow[t]{3}{*}{ Variovorax boronicumulans } & $\mathrm{Pb}(\mathrm{II})$ & $95.93 \%$ & 154 \\
\hline & $\mathrm{Cd}(\mathrm{II})$ & $73.45 \%$ & \\
\hline & $\mathrm{Zn}(\mathrm{II})$ & $73.81 \%$ & \\
\hline \multicolumn{4}{|l|}{ Fungi } \\
\hline \multirow[t]{2}{*}{ Aspergillus niger } & $\mathrm{Pb}(\mathrm{II})$ & $172 \mathrm{mg} \mathrm{g}^{-1}$ & 158 \\
\hline & $\mathrm{Cd}(\mathrm{II})$ & $11 \mathrm{mg} \mathrm{g}^{-1}$ & 159 \\
\hline \multirow[t]{2}{*}{ Aspergillus fumigatus } & $\mathrm{Cd}(\mathrm{II})$ & $74 \%$ & 104 \\
\hline & $\mathrm{Cr}(\mathrm{VI})$ & $48.2 \mathrm{mg} \mathrm{g}^{-1}$ & 160 \\
\hline \multirow[t]{2}{*}{ Aspergillus flavus } & $\mathrm{Pb}(\mathrm{II})$ & $12.45 \mathrm{mg} \mathrm{g}^{-1}$ & 76 \\
\hline & $\mathrm{Cd}(\mathrm{II})$ & $1.3 \mathrm{mg} \mathrm{g}^{-1}$ & \\
\hline \multirow[t]{6}{*}{ Acremonium sp. } & $\mathrm{Al}(\mathrm{III})$ & - & 161 \\
\hline & $\mathrm{Cu}(\mathrm{II})$ & & \\
\hline & $\mathrm{Fe}(\mathrm{II})$ & & \\
\hline & $\mathrm{Mn}(\mathrm{III})$ & & \\
\hline & $\mathrm{Pb}(\mathrm{II})$ & & \\
\hline & $\mathrm{Zn}(\mathrm{III})$ & & \\
\hline \multirow[t]{6}{*}{ Cellulosimicrobium sp. } & $\mathrm{Cd}(\mathrm{II})$ & $7.65 \%$ & 77 \\
\hline & $\mathrm{Cu}(\mathrm{II})$ & $21.21 \%$ & \\
\hline & $\mathrm{Fe}(\mathrm{II})$ & $70.26 \%$ & \\
\hline & $\mathrm{Ni}(\mathrm{II})$ & $18.98 \%$ & \\
\hline & $\mathrm{Pb}(\mathrm{II})$ & $24.12 \%$ & \\
\hline & $\mathrm{Zn}(\mathrm{II})$ & $22.82 \%$ & \\
\hline Termitomyces clypeatus & $\mathrm{Cr}(\mathrm{VI})$ & $403 \mathrm{mg} \mathrm{g}^{-1}$ & 162 \\
\hline \multirow[t]{3}{*}{ Penicillium chrysogenum } & $\mathrm{Pb}(\mathrm{II})$ & $11.55 \mathrm{mg} \mathrm{g}^{-1}$ & 76 \\
\hline & $\mathrm{Cr}(\mathrm{VI})$ & $0.10 \mathrm{mg} \mathrm{g}^{-1}$ & \\
\hline & $\mathrm{Cd}(\mathrm{II})$ & $0.51 \mathrm{mg} \mathrm{g}^{-1}$ & \\
\hline Trichoderma sp. & $\mathrm{Cd}(\mathrm{II})$ & $21.7 \mathrm{mg} \mathrm{g}^{-1}$ & 163 \\
\hline \multirow[t]{2}{*}{ Trichoderma viride } & $\mathrm{Cr}(\mathrm{IV})$ & $2.55 \mathrm{mg} \mathrm{g}^{-1}$ & 76 \\
\hline & $\mathrm{Pb}(\mathrm{II})$ & $9.14 \mathrm{mg} \mathrm{g}^{-1}$ & \\
\hline
\end{tabular}


Table 1. (Contd)

\begin{tabular}{lccc}
\hline Bacteria & $\begin{array}{c}\text { Heavy metals } \\
\text { studied }\end{array}$ & $\begin{array}{c}\text { Removal of } \\
\text { heavy metals }\end{array}$ & Reference \\
\hline S. cerevisiae & $\mathrm{Cu}(\mathrm{II})$ & $16 \mathrm{mg} \mathrm{g}^{-1}$ & 164 \\
Algae & & & \\
Chlamydomonas reinhardtii & $\mathrm{As}(\mathrm{III})$ & $38.6 \%$ & 165 \\
Chlorella vulgaris & $\mathrm{Pb}(\mathrm{II})$ & $72.9 \%$ & 166 \\
Cystoseira crinitophylla & $\mathrm{Cu}(\mathrm{II})$ & $160 \mathrm{mg} \mathrm{g}^{-1}$ & 167 \\
Fucus vesiculosus & $\mathrm{Pb}(\mathrm{II})$ & $229 \mathrm{mg} \mathrm{g}^{-1}$ & 168 \\
Sargassum sp. & $\mathrm{Cu}(\mathrm{II})$ & $49 \mathrm{mg} \mathrm{g}^{-1}$ & 169 \\
Sargassum filipendula & $\mathrm{Cd}(\mathrm{II})$ & $7.8 \mathrm{mg} \mathrm{g}^{-1}$ & 170 \\
Sargassum muticum & $\mathrm{Sb}(\mathrm{III})$ & $5.5 \mathrm{mg} \mathrm{g}^{-1}$ & 171 \\
Spirogyra sp. & $\mathrm{Cu}(\mathrm{II})$ & $87.2 \mathrm{mg} \mathrm{g}^{-1}$ & 172 \\
\hline
\end{tabular}

also describes metal-microbe interactions and metal resistance mechanisms in microbes which are essential for bioremediation of heavy metals. It also briefly discusses about the resistance mechanisms against mercury, arsenic, cadmium and lead.

\section{Metal-microbe interactions}

As mentioned earlier, constant metal exposure help microbes to get acquainted and develop resistance against the metal. Therefore, it becomes necessary to understand the nature of metal-microbe interactions. These interactions can divided into following types.

\section{Biosorption}

This is an interactive process in which metal ions bind non-specifically to polysaccharides and proteins present on the cell surface. It is a feature in which both living cells and dead microbial biomass provide binding sites and these binding sites can participate heavy metals even from highly dilute solutions ${ }^{20}$.

Bacteria exhibit metal adsorption because of the peptidoglycan layer present in them. Characteristic features of the peptidoglycan layer in Gram-positive and Gramnegative bacteria are different. Gram-positive bacteria exhibit multiple layers of peptidoglycan which consist of teichoic acid (unique to Gram-positive bacteria), amino acids (alanine and glutamate) and meso-diaminopimelic acid, while in Gram-negative bacteria, there is only one layer of peptidoglycan ${ }^{18}$. This layer consists of enzymes, glycoproteins, lipopolysaccharides and phospholipids ${ }^{3}$. These molecules act as ligands and offer active sites for metal-binding ${ }^{21,22}$. Teichoic acid and other acidic groups present in the cell wall are sources of carboxyl groups which play a crucial role in metal uptake ${ }^{23}$. Therefore, Gram-positive bacteria can adsorb more metal ions than Gram-negative bacteria. The cell wall also has complex carbohydrates, lipids, nucleic acids and proteins which constitute to form extra polymer substances (EPS). EPS show great metal-binding ability towards complex heavy metals and prevent their entry into the microbial intracellular environment. Thus, they protect microbes against heavy metal toxicity ${ }^{24}$. Sahmoune found that Streptomyces rimosus has good binding affinity for metals such as lead and iron ${ }^{25}$. A study performed by Rahman et al. $^{26}$, conclusively showed that a lead-resistant bacterium, Staphylococcus hominis strain AMB-2 could be effectively used for biosorption of lead and cadmium. Besides, multiple heavy metals could be biosorped by coral-associated solubilizing bacteria Cronobacter muytjensii KSCAS2 (ref. 27). Biological activities and applicability of EPS can be modified chemically by acetylation, carboxymethylation, methylation, phosphorylation and sulphonylation ${ }^{28}$. Besides, biofilms can also display adsorption of metals. It was demonstrated that Staphylococcus aureus biofilms could bio-precipitate U(IV), and further addition of acid phosphatase contributed to U(IV) remediation ${ }^{29}$.

In scientific studies, fungi have been extensively employed to carry out heavy metal adsorption. They have exhibited efficient metal-uptake ability and established themselves as good biosorbents ${ }^{29}$. This is because the fungal surface is composed of lipids such as chitins, glucans and mannins, proteins and polysaccharides. Mannan contains negatively charged groups such as amino groups, carboxyls, phosphates and sulphates. Various studies have been undertaken to check the fungal metalbinding ability. Say et al. ${ }^{30}$ demonstrated that mycelium of filamentous fungi Phanerochaeta chrysosporium can act as a biosorbent for cadmium, lead and copper. They further concluded that the mechanism and kinetics of biosorption were based on $\mathrm{pH}$ and availability of metal species. Sacharomyces cerevisiae has displayed the ability to remove toxic metals from contaminated wastewaters by biosorption ${ }^{31-33}$. Alternaria alternata and Penicillium aurantiogriseum have also been identified as good biosorbents for the removal of cadmium and mercury ${ }^{34}$.

Besides, photosynthetic organisms like algae have been reported to have good heavy metal absorption capabilities. Algal mass surface accumulates heavy-metal ions because it contains cell polymeric substances (peptides and polysaccharides), and polysaccharides such as alginate and cellulose, organic proteins and lipids and functional 
groups like carboxyl, amino, hydroxyl, phosphate, imidazole, thiol, sulphonate, etc. in the algal cell wall ${ }^{35}$. Algae also have deprotonated sulphate, laminaran and monomeric alcohols which attract both positive and negative species of different heavy metal ions ${ }^{36}$. Biosorption performance of different microalgal strains such as Spirulina platensis, Chlorella vulgaris, Oscillatoria sp. and Sargassam sp. was studied for metal ions ${ }^{37-39}$. Lin et al. ${ }^{40}$ carried out meta-analysis for heavy metal adsorption potential in different algal phyla and found that phaeophyta had the highest adsorption capacity. They also found that non-living algae were more efficient than living algae in terms of heavy metal biosorption ${ }^{40}$. Thus, algae can also serve as an important candidate in detoxification of heavy metals.

\section{Bioaccumulation}

This is a metabolically active process which depends on import-storage system. The system transports heavy metal ions across the lipid bilayer into the cytoplasm or intracellular spaces using transporter proteins. The metal ions are sequestered by metal-binding entities such as proteins and peptide ligands ${ }^{3}$, and the heavy metals which are sequestered by these entities can occur in the particulate forms, and insoluble forms and their by-products ${ }^{41}$.

In the bacterial membrane, heavy metal bioaccumulation mechanisms can be attributed to endocytosis, ion channels, carrier-mediated transport, complex permeation and lipid permeation ${ }^{2,42,43}$. Ahemad ${ }^{2}$ reported bioaccumulation studies of several metals such as mercury, lead, silver, cadmium and nickel. Rani and Goel ${ }^{44}$ studied cadmium using transmission electron microscopy, and found that Pseudomonas putida $62 \mathrm{BN}$ showed intracellular and periplasmic accumulation of the metal. Sher and Rehman $^{45}$ reported that Monodictys pelagic and Aspergillus niger can accumulate chromium and lead. More recently, Naskar et al. $^{46}$ demonstrated approximately $20 \%$ intracellular accumulation of nickel (II) in growing cells of Bacillus cereus M116.

\section{Bioleaching}

In bioleaching, microbes like bacteria and fungi which are present in nature, solubilize metal sulphides and oxides from ores deposits and secondary wastes ${ }^{47,48}$. The solubilized metals are then purified using suitable technologies which include adsorption, ion exchange, membrane separation and selective precipitation ${ }^{49}$. It is an economical and environment-friendly processes, as it uses less energy and does not emit harmful gases ${ }^{50}$. It has been used for centuries to leach metals from low-grade ores and currently supports a lucrative global market in the extraction of metals such as copper, cobalt, gold, nickel, uranium, zinc, etc. ${ }^{51}$.
Bioleaching can be achieved by contact and non-contact mechanisms. In contact mechanism, a non-random physical contact occurs between the mineral sulphide and bacterial cell ${ }^{52}$. Oxidation to sulphate occurs through several reactions catalysed by enzymes and causes electron transfer from the mineral surface ${ }^{53}$. In non-contact mechanism, there is no physical contact between the bacterial cell and mineral surface ${ }^{52}$. Bacteria generate lixiviant (ferric iron) which chemically oxidizes the sulphide mineral. This reaction occurs only in acidic environment below pH 5.0 (ref. 54). A wide range of microorganisms are involved in bioleaching and acidophiles occupy an important place. Acidophiles are chemolithotrophs which thrive well under low $\mathrm{pH}$ conditions, preferably 2.0 or less, and oxidize Fe(II) to Fe(III) and/or reduce sulphur to sulphuric acid. The resultant ferric ions and protons arise from sulphuric acid, and solubilize the metal sulphides and oxides from the ores ${ }^{55}$, thereby facilitating metal extraction by separating the metals in solid phase to more water soluble phase. Therefore, on summarizing these chemical reactions achieved by the microbes we find three basic steps ${ }^{56,57}$, viz. (i) microbial reduction-oxidation reaction in solution, (ii) formation of acid from inorganic and organic routes and (iii) metal extraction from the matrix.

Zhang and $\mathrm{Gu}^{58}$ reported that arsenic bioleaching is possible with both individual and mixed culture of Acidithiobacillus ferrooxidans and Acidithiobacillus thiooxidans. It was observed that mixed culture of the strains yielded higher bioleaching.

\section{Biomineralization}

Biomineralization of metal ions is a natural process of mineral formation. It occurs through natural synthesis of minerals such as carbonates, oxides, silicates, sulphates and phosphates, and involves different mechanisms attributed to the activities of living organisms ${ }^{59}$. Presence of highly variable and highly reactive interfaces such as cell wall and additional organic layers (EPS and S-layer) with different hydration, composition and structure are crucial factors for mineral formation. Besides, there are organic ligands such as amine, carboxyl, hydroxyl, phosphoryl and sulphur which deprotonate and impart net negative charge on the microbial surface with increase in $\mathrm{pH}^{60}$. Potential toxic metals having positive charge precipitate non-uniformly into more stable and compact mineral products ${ }^{61}$.

Metal immobilization or complexation can be achieved by phosphate precipitation, carbonate precipitation, oxalate precipitation, etc. ${ }^{62-65}$. Recently, numerous studies have demonstrated that remediation of toxic heavy metal ions such as copper, cadmium, lead, manganese, nickel, uranium and zinc can be achieved by biomineralization ${ }^{65-67}$. Zhang et al. ${ }^{61}$ also reported that Bacillus sp. could release 
free inorganic phosphate and trap toxic metal ions by the formation of an insoluble metal phosphate coat.

\section{Biotransformation}

This is the process by which the structure of a chemical compound is modified, leading to the synthesis of a molecule with relatively more polarity ${ }^{68,69}$. In other words, by this metal-microbe interaction process metal and organic compounds are modified from toxic form to a relatively less toxic form. This mechanism has been evolved in microbes to help them acclimatize with changes in the environment. Microbial cells have high surface-volume ratio, high growth rate, high rate of metabolic activity and maintenance of sterile condition is easy. Therefore, they are ideal for biotransformation. This process can be achieved through condensation, hydrolysis, formation of new carbon bonds, isomerization, introduction of functional groups, oxidation, reduction and methylation. These reactions may lead to volatization of metals and reduce their toxicity ${ }^{70}$.

Microbial transformation is being used widely for the transformation of various pollutants, including hydrocarbons, pharmaceutical substances and metals ${ }^{71}$. There are reports where microbes have been used to transform metals. Acinetobacter sp. and Micrococcus sp. oxidized toxic As(III) into harmless and less soluble As(III) and decreased its toxicity ${ }^{72}$. Thatoi et al. ${ }^{73}$ also provided evidence that $\mathrm{Cr}(\mathrm{VI})$-resistant Bacillus sp. SFC 500-1E can reduce toxic $\mathrm{Cr}(\mathrm{VI})$ to less toxic $\mathrm{Cr}(\mathrm{III})$ by NADHdependent reductase. Highly soluble and mobile U(VI) was transformed into highly insoluble $\mathrm{U}(\mathrm{IV})^{74}$.

\section{Microbial resistance mechanisms against heavy metals}

In heavy metal stress conditions, microbes either die of metal toxicity or survive by developing resistance mechanisms against metals. To be selected as potential agents of bioremediation, microbes must exhibit resistance mechanisms against metal toxicity. They can achieve resistance against heavy metals by five main mechanisms ${ }^{75}$ : (i) extracellular barriers, (ii) active transport of metal ions (efflux), (iii) extracellular sequestration, (iv) intracellular sequestration and (v) reduction of heavy metal ions.

\section{Extracellular barriers}

Cell wall, plasma membrane and other surface structures (EPS and biofilms) can act as barriers and prevent the entry of heavy metals inside the bacterial cells. Microbial cell surfaces exhibit a wide range of characteristics as discussed in metal-microbe interactions. They prevent the entry of metal ions by adsorbing them on their surface, indicating that they can act as barriers. For example, Kumar et al. ${ }^{76}$ demonstrated that fungal and bacterial isolates can act as biosorbents of heavy metals such as chromium, copper and lead. Gram-positive bacteria, Cellulosimicrobium sp. also showed resistance against multiple heavy metals such as copper, cadmium, iron, zinc, lead and nickel. This resistance mechanism was mediated by chemisorption sites ${ }^{77}$.

Microbes produce biofilms which act as barriers. Biofilms constitute extracellular polymers which can accumulate metal ions and consequently safeguard cells inside them. Biofilm cells of Pseudomonas aeruginosa demonstrated resistance against copper, lead and zinc ions $^{78}$. In Rhodotorula mucilaginosa, biofilms increased metal removing efficiency from $91.71 \%$ to $95.35 \%$ (ref. 79).

Besides cell wall and biofilms, there are studies which show that EPS can also act as a barrier to metals. Adsorption of lead ions was reported in P. aeruginosa, Acinetobacter junii L. Pb1 and Azotobacter chroococcum XU1 (refs 80-82). Kazy et al. ${ }^{83}$ observed that EPS provided copper resistance to $P$. aeruginosa. Copper-resistant strain produced twice the amount of EPS than the sensitive strain. In addition, entry of metal ions into the cells can be prevented by changing the permeability of the plasma membrane.

\section{Active transport of metal ions}

This is a key mechanism for heavy metal resistance in microbes. Efflux pumps remove heavy metals and maintain homeostasis. Metals can enter inside the cell through the same transport channel system from where essential elements enter. For example, in Ralstonia metallidurans, chromium enters through the sulphate transport system and facilitates ions of cadmium, zinc, cobalt and nickel, while manganese enters through the magnesium transport system $^{84}$. Uptake of arsenate and arsenite by arsenicresistant microbes (Escherichia coli) mediated by GlpF and phosphate transporters (Pst and Pit pumps) is also a good example ${ }^{85}$. Excessive concentration of these heavy ions is removed by the energy-dependent efflux system. For instance, $\mathrm{Cu}$ efflux in $E$. coli is controlled by a RND CusCBA multiprotein complex ${ }^{86}$. Bacillus sp. SFC 500$1 \mathrm{E}$ carries out efflux of toxic chromate ions $\mathrm{Cr}(\mathrm{VI})$ by a chromate ion transporter protein known as $\mathrm{ChrA}^{87}$.

In $R$. metallidurans $\mathrm{CH} 34$, efflux of metal ions is mediated by the $\mathrm{CzcCB} 2 \mathrm{~A}$ complex ${ }^{88}$. In some bacteria, the efflux system works with other heavy metal resistance mechanisms for removing metals ${ }^{89}$. In Gram-positive and Gram-negative bacteria, the ars operon system encodes for ATPase pump, ArsA/ArsB and ArsC (arsenic reductase). ArsC is known to reduce arsenate to arsenite in the cytoplasm, and the efflux mechanism involves export of 
arsenite outside through the plasma membrane ${ }^{90}$. Shewanella oneidensis MR1 also demonstrated tolerance mechanisms of metal efflux and biotransformation. The host cell removed and decreased the concentration of intracellular chromium by the efflux system and consequently allowed cells damaged by chromium to grow and detoxify it over extended periods of time ${ }^{91}$.

\section{Extracellular sequestration}

In extracellular sequestration cellular components present in the periplasm or the outer membrane form a complex with metal ions. Besides, the mechanism can also involve formation of insoluble compounds due to metal-ion complexation $^{92}$. Pseudomonas syringae, a copper-resistant strain synthesizes copper-inducible proteins. These proteins bind with copper ions and accumulate them, and turn bacterial colonies blue ${ }^{93}$. Copper-tolerant Pseudomonas pickettii US321 strain also exhibits the same phenomenon. Gilotra and Srivastava ${ }^{94}$ observed that the resistant strain accumulated copper as a complex and transported it into the cytoplasm, while the sensitive strain accumulated copper in a free ionic form which is highly toxic to the cell.

It was demonstrated that under aerobic condition, Klebsiella planticola produces hydrogen sulphide from thiosulphate and precipitates cadmium ions as insoluble sulphides ${ }^{95}$. Under carbon-limiting conditions multiresistant Pseudomonas putida S4 strain forms an insoluble precipitate composed of copper ions, hydroxyl and phosphate residues ${ }^{96}$. Desulfovibrio desulfuricans produces hydrogen sulphide in the extracellular environment which protects the host cell from heavy metal toxicity by metal-ion precipitaion ${ }^{97}$.

\section{Intracellular sequestration}

Metal ions are harmful to sensitive cellular components at toxic levels. Therefore, these metal ions are sequestered inside the cytoplasm and prevented from reaching toxic levels. Intracellular sequestration involves formation of a complex between metal ions and metal-binding peptides in the cytoplasm ${ }^{75}$.

Metal-binding peptides in eukaryotes are of two types-metallothioneins and phytochelatins. Both are cystein-rich and metal ions bind by sulfhydryl groups ${ }^{98}$. Metallothioneins are metalloproteins which have high metal-binding affinity. They are induced in the presence of heavy metal ions ${ }^{99}$. Cysteine residues in metallothioneins may serve as a sink when toxic metal ions are in excess $^{97}$. The ability to synthesize metallothionein was demonstrated by the cyanobacterium Synechococcus sp. PCC 7942, in which the smtA and $s m t B$ genes were responsible for its synthesis ${ }^{100}$. Consequently, it resulted in the sequestration of cadmium and zinc by methionein binding ${ }^{101}$. In microalgae, metallothioneins are highly diverse and potential novel forms help them survive in heavy metal-contaminated environments. Few examples of such microalgae genera include Chlamydomonas, Chlorella and Scenedesmus ${ }^{102}$.

Phytochelatins are peptides which have low molecular weight and are found in fungi and plants. They are synthesized from glutathione and have 5-11 amino acid residues $^{103}$. Ianieva ${ }^{75}$ observed that glutathione in Rhizobium leguminosarum cells could sequester cadmium ions intracellularly. Talukdar et al. ${ }^{104}$ reported that the fraction of chromium (IV) ions that enters into the Aspergillus sp. are sequestered by glutathione and converted into less toxic form, and ultimately thrown out of the system through the efflux system.

\section{Reduction of heavy metal ions}

Metals and metalloids have a wide range of high oxidation states which can be reduced by enzymes to form more stable and less toxic metal forms ${ }^{105}$. Some bacteria use metals and metalloids as electron donors or acceptors to generate energy. In bacteria, during anaerobic respiration, the oxidized form of metals can act as terminal acceptors of electrons. Several studies report reduction of heavy metals by bacteria. Smirnova ${ }^{106}$ isolated bacteria from different ecological niches which reduced chromate, molybdate and vanadate. Joshi et al. ${ }^{107}$ reported that Geobacter sulfurreducens uses naturally abundant iron (III) minerals and produces magnetic iron (II)-bearing nanoparticles. These bio-nanoparticles have the potential to reduce mobile and toxic chromium (VI) to soluble and less toxic chromium (III). Ma et al. ${ }^{108}$ reported that chromium (IV) was reduced to less toxic form by bacterial consortium. Detoxification of mercury ions by mercuric reductase encoded by mer operon also serves as a good example.

\section{Genetic determinants of heavy metal resistance in bacteria}

Nanda et $a l{ }^{18}$ reported that bacteria can grow almost everywhere and their ubiquitousness has provided them with an opportunity of being exposed to a wide range of metal toxicity. Over the course of evolution, they have tolerated and developed resistance mechanisms against heavy metals such as arsenic, copper, cadmium, chromium, mercury, nickel, lead, etc. Metal resistance in bacteria and fungi is due to resistance genes found on the chromosomes and plasmids. However, the resistance mechanisms mediated by the chromosomes and plasmids vary. The resistance mechanisms encoded by chromosomes are more complex than those of plasmids.

The genetic determinants responsible for metal resistance were first discovered in plasmids ${ }^{109}$. Operon 
systems in plasmids can serve as heavy metal genetic determinants. For example, the $c z c$ operon in $R$. metallidurans $\mathrm{CH} 34$ plasmid PMOL30 acts as a genetic determinant for resistance against cadmium, zinc and cobalt. Another plasmid, PMOL28 is also present in these bacterial systems which localizes the $c n r$ operon that serves as a genetic determinant for cobalt, nickel and chromium $^{110}$. Both plasmids in the bacterium also confer resistance against mercury and titanium. According to Nies ${ }^{111}$ and Cooksey ${ }^{112}$ the genetic determinant, cop operon for copper resistance is found in Pseudomonas sp. plasmid. This operon is induced by the presence of copper and encodes four proteins, namely $\operatorname{CopA}, \operatorname{CopB}$, CopC and CopD. The Cop proteins accumulate copper ions and simultaneously form compartments in the cell periplasm and outer membrane. There are also instances where genetic determinants for metal resistance are localized in the chromosome. One example of such a case is the ATP-driven active transport system involving efflux of zinc ions across the plasma membrane. Here, the zntA gene encodes chromosomal regulation of P-type ATPase ${ }^{113}$.

It has been reported that several bacteria may have similar metal resistance mechanisms in both plasmids and chromosomes. For example, ars operons in the chromosomes of E. coli, P. aeruginosa and B. subtilis are structurally similar to genetic determinants, ars operons found in the plasmids ${ }^{90}$. However, the systems may be different as the rule suggests that essential metal ion homeostasis genes should be localized in the chromosomes, while toxic metal resistance genes should be localized in the plasmids $^{114,115}$.

Metal resistance mechanisms are attributed to resistance gene systems located in the plasmids or/and chromosomes. Therefore, identification and characterization of these genetic determinants become crucial for the understanding and characterization of tolerance, which could be essential to devise an efficient bioremediation strategy.

\section{Mercury resistance mechanism and bioremediation}

Mercury is a heavy metal with the strongest toxicity; so, it has no beneficial functions. Bacteria being ubiquitous are likely to confront toxic $\mathrm{Hg}$ (II) concentrations ${ }^{111}$. The mer operon, mercury resistance determinant is widespread in bacteria ${ }^{116}$. In Gram-positive and Gramnegative bacteria, it is located in the plasmids. It comprises merR and merD genes (regulatory genes), merT and merP genes (transport genes) and mer $A$ gene (gene encoding mercuric reductase) ${ }^{117}$.

In Gram-positive bacteria periplasm, $\mathrm{Hg}$ (II)-binds with $\mathrm{Hg}(\mathrm{II})$-binding protein, MerP. This helps in preventing $\mathrm{Hg}$ (II) toxicity in periplasmic proteins. MerP delivers $\mathrm{Hg}$ (II) ions to another transporter protein, MerT which transports the toxic metal ions into the cytoplasm. In con- trast, $\mathrm{Hg}(\mathrm{II})$ ions are transported inside the cytoplasm via specific uptake systems in Gram-negative bacteria. It is to be noted that there is another transport system by MerC, which can be either addition or substitution to MerT ${ }^{118}$. As $\mathrm{Hg}(\mathrm{II})$ ions enter inside the cell, NADPH-dependent mercuric reductase (MerA) reduces them to $\mathrm{Hg}(0)^{119}$. Organomercurials are more toxic than $\mathrm{Hg}$ (II). To detoxify them, the mer operon must encode a MerB organomercurial lyase along with other Mer proteins. The MerB protein first cleaves organomercurials into $\mathrm{Hg}(\mathrm{II})$, and then it is reduced by MerA ${ }^{117,120}$. Barkay et al. ${ }^{105}$ reported that there are five different mechanisms of mercury resistance. These include: (i) reduction in mercuric ions uptake, (ii) conversion of demethylated methylmercury to compounds of mercuric sulphide, (iii) sequestration of methylmercury, (iv) methylation of mercury and (v) reduction of $\mathrm{Hg}$ (II) to $\mathrm{Hg}(0)$.

A Chang et al. ${ }^{121}$ reported that mercury resistance in filamentous fungus, Penicillium sp. DC-F11 obtained from a heavy metal-contaminated site is a multisystem collaborative process. Extracellular sequestration such as adsorption and precipitation help the fungal cells to detoxify $\mathrm{Hg}$ (II) ions. The intracellular response to $\mathrm{Hg}$ (II) stress according to comparative transcriptome analysis includes thiol compound metabolism, mer-mediated detoxification system, defense against oxidative stress and metabolism for damage repair. They further claimed to have reported for the first a fungus using detoxification system for $\mathrm{Hg}(\mathrm{II})$ volatization through the mer operon.

\section{Arsenic resistance mechanism and bioremediation}

Arsenic is a toxic heavy metal which enters inside the microbes through phosphate transport system and gets accumulated. However, its presence can be toxic; therefore microbes have developed resistance mechanism against it. Arsenic resistance is attributed to the ars operon which is present in plasmids or/and chromosomes ${ }^{111}$. For example, in E. coli it is found in both plasmids and chromosomes whereas in $S$. aureus it is found only in the plasmids. In E. coli, plasmid R773 consists of five genes, viz. $\operatorname{ars} R, \operatorname{ars} D, \operatorname{ars} A, \operatorname{ars} B$ and $\operatorname{ars} C$. Therefore, the whole gene sequence in the cluster is known as arsRDABC. The ars operon in $S$. aureus plasmid pI 258 is different from that of $E$. coli and it has three genes, viz. $\operatorname{ars} R, \operatorname{ars} B$ and $\operatorname{ars} C$ (refs 111, 122). In arsenic-resistant microbes, different genes encode for different protein molecules. ars $R$ encodes for the repressor protein which is induced by the presence of arsenate, arsenite, antimonite and bismuth. $\operatorname{ars} B$ encodes for the arsenic efflux pump. ars $C$ encodes for the intracellular enzyme known as arsenate reductase. Arsenate reducatase reduces $\mathrm{As}(\mathrm{V})$ to $\mathrm{As}(\mathrm{III})$. $\operatorname{ars} A$ encodes for intracellular ATPase protein and ars $B$ plays an important role in chemiosmosis ${ }^{122-124}$. 
Once arsenate reaches inside the microbial cell, it may accumulate and cause toxicity. Therefore, it should be removed from the cell. However, it is difficult to remove the metal ion as it shares structural similarity with phosphate which is high in concentration. It becomes difficult to export arsenate effectively ${ }^{125}$. Therefore, there should be a mechanism to distinguish it from phosphate, and here comes the role of arsenate reductase. It reduces $\mathrm{As}(\mathrm{V})$ to $\mathrm{As}(\mathrm{III})$, and the microbial cell exits As(III) through the efflux pump. Interestingly, the efflux pump specifically for arsenate still remains unknown ${ }^{45}$. In $E$. coli, the ArsC protein couples with glutathione via glutaredoxin to reduce arsenate and in $S$. aureus, the electron donor is thioredoxin ${ }^{111,126}$.

Wu et al. ${ }^{127}$ proposed that Alishewanella sp. WH16-1 resistance against As(III) is mediated by $R u v R C A B$. As(III) enters inside the cells through transporter systems and causes rearrangement of DNA. The RuvR gene positively regulates expression of $R u v C A B$ and repairs the DNA damage. This DNA repairing mechanism against heavy metals by $R u v C A B$ may be largely confined to Gram-negative bacteria. In another study on arsenic resistance mechanism, complete genome analysis of $P$. putida was performed. It was discovered that 61 ORFs (open reading frames) were involved in metal resistance suggesting multiple metal resistance, with seven ORFs being most crucial in metal resistance mechanisms. It included two arsenic resistance systems, two cadA, two operons for copper chelation and one for chromate ions. Some proteins were also involved in multiple metal resistance ${ }^{128}$.

\section{Cadmium resistance mechanism and bioremediation}

Cadmium is the best known toxic heavy metal. It may enter inside the microbial cells ( $R$. metallidurans $\mathrm{CH} 34$ and $S$. aureus $)^{129,130}$ and accumulate via the magnesium transport system. It may also enter inside other microbial cells through any manganese uptake system. However, molecular-level understanding of $\mathrm{Cd}(\mathrm{II})$ uptake is still lacking ${ }^{11}$. Cadmium efflux forms the basis of $\mathrm{Cd}(\mathrm{II})$ resistance in bacteria. Cd(II) resistance in Gram-positive bacteria is attributed to CadA protein, which is also known as Cd(II) efflux P-type ATPase. The synthesis of CadA protein is induced by the presence of $\mathrm{Cd}(\mathrm{II})$ ions. The CadA protein from Staphylococcus plasmid pI258 was the first to be sequenced, and it is 727 amino acids long. The basic model of CadA protein proposed by Silver and Walderhaug ${ }^{131}$ hypothesized that it has three cytoplasmic domains: The first domain is homologous to MerP and MerA proteins of mercury resistance and involves in $\mathrm{Cd}(\mathrm{II})$ binding. The second domain functions as a channel to funnel out $\mathrm{Cd}$ (II) ions and prevent initial binding of microbial membrane. It also functions as phosphatase and removes phosphate Asp415-Pi. The third domain consists of an ATP-binding motif and a heptapeptide aspartyl kinase. It is most widely distributed among
Gram-positive bacteria which include Bacillus, Listeria and Staphylococcus ${ }^{115}$.

In $S$. aureus, Cd-mediated resistance is imparted by $c a d A$ and $c a d B$ operons which are present in the plasmids. The $c a d A$ operon present in plasmid pI258 contains two genes, $c a d A$ and $c a d C$. cadA encodes for a protein which is 727 amino acids long and shows sequence similar to the P-class of ATPases. Cd enters inside S. aureus cells through an active transport system which is $\mathrm{Mn}^{2+}$ specific, and gets accumulated to toxic levels ${ }^{132}$. These accumulated $\mathrm{Cd}$ (II) ions are then transported outside by CadA protein, consequently leading to their removal from the bacterial cell. cadC encodes for the CadC protein which is 122 amino acids long and regulates transcription of cadmium operon. Thus, products of $c a d A$ and $c a d C$ genes are integral for cadmium resistance ${ }^{115}$. The $c a d B$ operon differs significantly from the $\operatorname{cad} A$ operon. It resides in an incompatibility group II in $S$. aureus plasmid (pII147) and consists of two genes, $c a d B$ and $c a d X$. In $S$. aureus cells (pII147 containing), there is no intracellular bioaccumulation of $\mathrm{Cd}(\mathrm{II})$ ions despite $\mathrm{Mn}^{2+}$-specific transport system being active. Moreover, it has also been proposed that $C a d B$ could bind with $\mathrm{Cd}$ ions in the membrane, but does not promote their efflux ${ }^{133}$.

In Gram-negative bacteria, cadmium resistance is mediated by RND-driven zinc exporter, viz. the Czc system $^{111,117}$ and a nickel exporter, $\mathrm{Ncc}^{134}$. In $R$. metallidurans plasmid pMOL30 the $c z c$ operon has been reported, where it stands for cadmium, zinc and cobalt. It consists of three structural genes: $c z c A, c z c B$ and $c z c C$. $c z c A$ is essential for the three above-mentioned heavy metals. It encodes for an anti-porter cation carrier which resides inside the membrane. $c z c B$ encodes for $\mathrm{CzcB}$ protein which plays an ancillary role in cation transportation. Deletion of this gene will result in complete loss of resistance against $\mathrm{Cd}(\mathrm{II})$ and $\mathrm{Zn}$ (II). $c z c C$ encodes for the outer membrane $\mathrm{CzcC}$ protein. These three proteins form a complex membrane cation efflux pump (CzcABC complex) for $\mathrm{Cd}(\mathrm{II})$ detoxification. Besides, $c z c R$ and $c z c D$ genes are also present which are involved in $c z c$ operon expression ${ }^{135}$.

In yeast $S$. cerevisiae, $\mathrm{Cd}$ resistance is mediated by glutathione. It has been reported that incoming $\mathrm{Cd}(\mathrm{II})$ ions were bound by glutathione to form cadmiumbisglutathionato complex. This complex is later transported into the vacuole by the YCF1p transporter, which is an $\mathrm{ABC}$ transporter ${ }^{136,137}$. In cyanobacteria, cadmium resistance is conferred by smt operon which consists of two genes, $s m t A$ and $s m t B$. The former encodes for Mts protein which is crucial for $\mathrm{Cd}$ tolerance ${ }^{138}$, while the latter regulates $s m t A$ gene expression and the operatorpromoter region that exists between the two genes ${ }^{139}$.

\section{Lead resistance mechanism and bioremediation}

The first lead-specific resistance determinant system was described by Borremans et al. ${ }^{140}$ in $R$. metallidurans 
CH34 plasmid pMOL30. Pb resistance is conferred by the $p b r$ operon. For $\mathrm{Pb}$ (II) detoxification, it combines metal uptake, accumulation and efflux of $\mathrm{Pb}(\mathrm{II})$. The $p b r$ operon consists of several resistance genes such as $p b r T$, $p b r A, p b r B, p b r C, p b r D$ and $p b r R$. $\mathrm{Pb}(\mathrm{II})$ uptake into the cytoplasm is achieved with the help of PbrT protein. Once inside the host cytoplasm, $\mathrm{Pb}$ (II) is excreted out through the $p b r A$ gene-encoded P-type ATPase, or it may bind to the PbrD protein which is capable of being a chaperone molecule. However, it should be noted that the $\mathrm{PbrD}$ protein is not a necessity for $\mathrm{Pb}$ (II) resistance, but cells without PbrD protein may show reduced bioaccumulation. This internal sequestration of $\mathrm{Pb}(\mathrm{II})$ ions may protect against those metal ions which are exported freely, and prevent the uptake-export futile cycle of metal ions. The P-type ATPase efflux system may appear sufficient for $\mathrm{Pb}$ (II) resistance but for complete $\mathrm{Pb}$ (II) resistance, $\mathrm{PbrB}$ and $\mathrm{PbrC}$ proteins are also essential. PbrB and associated integral membrane protein are considered to be part of transporter-assisting resistance proteins, and may transport $\mathrm{Pb}(\mathrm{II})$ ions from the periplasm to the outer membrane. This would decrease $\mathrm{Pb}(\mathrm{II})$ uptake by $\mathrm{PbrT}$ protein. The $p b r C$ gene encodes for prolipoprotein signal peptidase and is a crucial entity in the $p b r$ operon. $p b r B$ and $p b r C$ genes belong to the same transcriptional unit; therefore, it can be hypothesized that the $\mathrm{PbrC}$ prolipoprotein signal peptidase is essential for $\mathrm{PbrB}$ prolipoprotein processing, and vice versa.

In $R$. metallidurans $\mathrm{CH} 34$ chromosome, $p b r R$ and its homologues show remarkable affinity towards $\mathrm{Pb}(\mathrm{II})$ ions and are considered to be the only characterized natural metalloproteins. A computational study was carried out by Tolbatov et al. ${ }^{141}$ on the affinity of $\mathrm{Pb}$ (II) towards the pbrR protein. It was found that pbrR may regulate its affinity towards $\mathrm{Pb}(\mathrm{II})$ ions by changing its conformation and protonation states. Hence, it is able to initiate metal sequestration or release the ions in response to external stimuli. Studies of such evolutionarily developed microbial resistance mechanisms are of utmost importance to devise novel strategies to carry out metal isolation and bioremediation.

Pd resistance in P. aeruginosa N6P6 is mediated by expression of bmtA genes. These genes encode for metallothionein which maintains intracellular homeostasis of essential metal ions. It is interesting to note that with increase in $\mathrm{Pb}(\mathrm{II})$ ion concentration, the expression of $b m t A$ genes also increases. Besides, $b m t A$ genes were also induced by other heavy metals which include mercury, copper, cadmium and arsenic ${ }^{118}$.

\section{Future prospects and conclusion}

This article shows that use of microorganisms for heavy metal bioremediation is environment-friendly, efficient and cost-effective. Microbes are ubiquitous and show fast growth. In heavy metal-contaminated sites, they become accustomed to heavy metal ions. They interact with the metal ions and consequently develop strategies of tolerance and resistance against them. Knowledge of genetics and resistance mechanisms against heavy metals has helped in finding solutions to heavy metal pollution. More research should be directed towards finding newer strategies that can be adopted for metal detoxification and restoring heavy metal-contaminated sites. Microbial remediation is further made efficient by genetically engineered microorganisms (GEMs), but they do have some legal, ethical and biosafety issues. Besides, efficiency of GEMs in field conditions is always a matter of concern. Therefore, extensive research on GEMs in accordance with biosafety guidelines is necessary.

1. Ojuederie, O. B. and Babalola, O. O., Microbial and plantassisted bioremediation of heavy metal polluted environments: a review. Int. J. Environ. Res. Public Health, 2017, 14, 1504.

2. Ahemad, M., Implications of bacterial resistance against heavy metals in bioremediation: a review. IIOAB J., 2012, 3, 39-46.

3. Ayangbenro, A. S. and Babalola, O. O., A new strategy for heavy metal polluted environments: a review of microbial biosorbents. Int. J. Environ. Res. Public Health, 2017, 14, 94.

4. Kumar, N. M., Muthukumaran, C., Sharmila, G. and Gurunathan, B., Genetically modified organisms and its impact on the enhancement of bioremediation. In Bioremediation: Applications for Environmental Protection and Management (ed. Varjani, S.), Springer, Singapore, 2018, pp. 53-76.

5. Jaishankar, M., Tseten, T., Anbalagan, N., Mathew, B. B. and Beeregowda, K. N., Toxicity, mechanism and health effects of some heavy metals. Interdiscip. Toxicol., 2014, 7, 60-72.

6. Valko, M. et al., Redox and nonredox-metal-induced formation of free radicals and their role in human disease. Arch. Toxicol., 2016, 90, 1-37.

7. Edelstein, M. and Ben-Hur, M., Heavy metals and metalloids: sources, risks and strategies to reduce their accumulation in horticultural crops. Sci. Hortic., 2018, 234, 431-444.

8. Nagajyoti, P. C., Lee, K. D. and Sreekanth, T. V. M., Heavy metals, occurrence and toxicity in plants: a review. Environ. Chem. Lett., 2010, 8, 199-216.

9. Garg, N. and Singla, P., Arsenic toxicity in crop plants: physiological effects and tolerance mechanisms. Environ. Chem. Lett., $2011,9,303-316$.

10. Fashola, M., Ngole-Jeme, V. and Babalola, O., Heavy metal pollution from gold mines: environmental effects and bacterial strategies for resistance. Int. J. Environ. Res. Public Health, 2016, 13, 1047.

11. Jalmi, S. K., Bhagat, P. K., Verma, D., Noryang, S., Tayyeba, S. and Singh, K., Traversing the links between heavy metal stress and plant signaling. Front. Plant Sci., 2018, 9, 12.

12. Gordon, T. and Bowser, D., Beryllium: genotoxicity and carcinogenicity. Mutat. Res. Fundam. Mol. Mech. Mutagen., 2003, 533, 99-105.

13. Chibuike, G. and Obiora, S., Heavy metal polluted soils: effect on plants and bioremediation methods. Appl. Environ. Soil Sci., 2014, 2014, 1-12.

14. Fu, F. and Wang, Q., Removal of heavy metal ions from wastewaters: a review. J. Environ. Manage., 2011, 92, 407-418.

15. Aziz, H. A., Adlan, M. N. and Ariffin, K. S., Heavy metals (Cd, $\mathrm{Pb}, \mathrm{Zn}, \mathrm{Ni}, \mathrm{Cu}$ and $\mathrm{Cr}(\mathrm{III}))$ removal from water in Malaysia: post treatment by high quality limestone. Bioresour. Technol., 2008, 99, 1578 . 
16. Barakat, M. A., New trends in removing heavy metals from industrial wastewater. Arab. J. Chem., 2011, 4, 361-377.

17. Hakizimana, J. N., Gourich, B., Chafi, M., Stiriba, Y., Vial, C., Drogui, P. and Naja, J., Electrocoagulation process in water treatment: a review of electrocoagulation modeling approaches. Desalination, 2017, 404, 1-21.

18. Nanda, M., Kumar, V. and Singh, D. K., Multimetal tolerance mechanisms in bacteria: the resistance strategies acquired by bacteria that can be exploited to 'clean-up' heavy metal contaminants from water. Aquat. Toxicol., 2019, 212, 1-10.

19. Kumar, A., Bisht, B. S., Joshi, V. D. and Dhewa, T., Review on bioremediation of polluted environment: a management tool. Int J. Environ. Sci., 2011, 1, 1079-1093.

20. Vasudevan, P., Padmavathy, V., Tewari, N. and Dhingra, S. C., Biosorption of heavy metal ions. J. Sci. Ind. Res. India, 2001, 60, 112-120.

21. Fomina, M. and Gadd, G. M., Biosorption: current perspectives on concept, definition and application. Bioresour. Technol., 2014, 160, 3-14.

22. Gupta, V. K., Nayak, A. and Agarwal, S., Bioadsorbents for remediation of heavy metals: Current status and their future prospects. Environ. Eng. Res., 2015, 20, 1-18.

23. Hoyle, B. and Beveridge, T. J., Binding of metallic ions to the outer membrane of Escherichia coli. Appl. Environ. Microbiol., $1983,46,749-752$

24. Gupta, P. and Diwan, B., Bacterial exopolysaccharide mediated heavy metal removal: a review on biosynthesis, mechanism and remediation strategies. Biotechnol. Rep., 2016, 13, 58-71.

25. Sahmoune, M. N., Performance of Streptomyces rimosus biomass in biosorption of heavy metals from aqueous solutions. Microchem. J., 2018, 141, 87-95.

26. Rahman, Z., Thomas, L. and Singh, V. P., Biosorption of heavy metals by a lead $(\mathrm{Pb})$ resistant bacterium, Staphylococcus hominis strain AMB-2. J. Basic Microbiol., 2019, 59, 477-486.

27. Saranya, K., Sundaramanickam, A., Shekhar, S., Meena, M. Sathishkumar, R. S. and Balasubramanian, T., Biosorption of multi-heavy metals by coral associated phosphate solubilising bacteria Cronobacter muytjensii KSCAS2. J. Environ. Manage. 2018, 222, 396-401.

28. Verma, S. and Kuila, A., Bioremediation of heavy metals by microbial process. Environ. Technol. Innov., 2019, 14, 100369.

29. Shukla, S. K., Hariharan, S. and Rao, T. S., Uranium bioremediation by acid phosphatase activity of Staphylococcus aureus biofilms: can a foe turn a friend? J. Hazard. Mater., 2019, 384 121316.

30. Say, R., Denizli, A. and Arica, M. Y., Biosorption of cadmium(II), lead(II) and copper(II) with the filamentous fungus Phanerochaete chrysosporium. Bioresour. Technol., 2000, 76 , 67-70.

31. Machado, M. D., Soares, E. V. and Soares, H. M., Removal of heavy metals using a brewer's yeast strain of Saccharomyces cerevisiae: chemical speciation as a tool in the prediction and improving of treatment efficiency of real electroplating effluents J. Hazard. Mater., 2010, 180, 347-353.

32. Fu, Y. Q., Li, S, Zhu, H. Y., Jiang, R. and Yin, L. F., Biosorption of copper(II) from aqueous solution by mycelial pellets of Rhizopus oryzae. Afr. J. Biotechnol., 2012, 11, 1403-1411.

33. Li, C., Xu, Y., Wei, J., Dong, X. and Liu, B., Effect of $\mathrm{NaCl}$ on the heavy metal tolerance and bioaccumulation of Zygosaccharomyces rouxii and Saccharomyces cerevisiae. Bioresour. Technol., 2013, 143, 46-52.

34. Bahobil, A., Bayoumi, R. A., Atta, H. M. and El-Sehrawey, M. M., Fungal biosorption for cadmium and mercury heavy metal ions isolated from some polluted localities in KSA. Int. J. Curr. Microbiol. Appl. Sci., 2017, 6, 2138-2154.

35. Priatni, S., Ratnaningrum, D., Warya, S. and Audina, E., Phycobiliproteins production and heavy metals reduction ability of
Porphyridium sp. IOP Conf. Series Earth Environ. Sci., 2017, 160, 012006 .

36. Pradhan, D., Shukla, L. B., Mishra, B. B. and Devi, N., Biosorption for removel of hexavalent chromium using microalgae Scenedesmus sp. J. Clean. Prod., 2019, 209, 617-629.

37. Leong, Y. K. and Chang, J. S., Bioremediation of heavy metals using microalgae: recent advances and mechanisms. Bioresour. Technol., 2020, 303, 122886.

38. Riskuwa-Shehu, M. L., Ismail, H. Y. and Sulaiman, M., Biosorption of heavy metals by Oscillatoria species. Microbiol. Res. J. Int., 2019, 27, 1-8.

39. Sayadi, M. H., Rashki, O. and Shahri, E., Application of modified Spirulina platensis and Chlorella vulgaris powder on the adsorption of heavy metals from aqueous solutions. J. Environ. Chem. Eng., 2019, 7, 103169.

40. Lin, Z., Li, J., Luan, Y. and Dai, W., Application of algae for heavy metal adsorption: a 20-year meta-analysis. Ecotoxicol. Environ. Saf., 2020, 190, 110089.

41. Mishra, A. and Malik, A., Recent advances in microbial metal bioaccumulation. Crit. Rev. Environ. Sci. Technol., 2013, 43, 1162-1222.

42. Geva, P., Kahta, R., Nakonechny, F., Aronov, S. and Nisnevitch, M., Increased copper bioremediation ability of new transgenic and adapted Saccharomyces cerevisiae strains. ESPR, 2016, 23 19613-19625.

43. Shahpiri, A. and Mohammadzadeh, A., Mercury removal by engineered Escherichia coli cells expressing different rice metallothionein isoforms. Ann. Microbiol., 2018, 68, 145-152.

44. Rani, A. and Goel, R., Strategies for crop improvement in contaminated soils using metal-tolerant bioinoculants. In Microbial Strategies for Crop Improvement (eds Khan, M. S., Zaidi. A. and Musarrat, J.), Springer, Berlin, 2009, pp. 105-132.

45. Sher, S. and Rehman, A., Use of heavy metals resistant bacteria a strategy for arsenic bioremediation. Appl. Microbiol. Biotechnol., 2019, 103, 6007-6021.

46. Naskar, A., Majumder, R. and Goswami, M., Bioaccumulation of $\mathrm{Ni}(\mathrm{II})$ on growing cells of Bacillus sp.: response surface modeling and mechanistic insight. Environ. Technol. Innov., 2020, 20, 101057

47. Mishra, D., Kim, D. J., Ahn, J. G. and Rhee, Y. H., Bioleaching: a microbial process of metal recovery; a review. Met. Mater. Int., 2005, 11, 249-256.

48. Jafari, M., Abdollahi, H., Shafaei, S. Z., Gharabaghi, M., Jafari, H., Akcil, A. and Panda, S., Acidophilic bioleaching: a review on the process and effect of organic-inorganic reagents and materials on its efficiency. Min. Proc. Ext. Met. Rev., 2019, 40, 87-107.

49. Rohwerder, T., Gehrke, T., Kinzler, K. and Sand, W., Bioleaching review part A. Appl. Microbiol. Biotechnol., 2003, 63, 239-248.

50. Asghari, I., Mousavi, S. M., Amiri, F. and Tavassoli, S., Bioleaching of spent refinery catalysts: a review. Ind. Eng. Chem. Res., 2013, 19, 1069-1081.

51. Lloyd, J. R., Bioremediation of metals; the application of microorganisms that make and break minerals. Microbiol. Today, 2002, 29, 67-69.

52. Anjum, F., Shahid, M. and Akcil, A., Biohydrometallurgy techniques of low grade ores: a review on black shale. Hydrometallurgy, 2012, 117, 1-12.

53. Brandl, H., Microbial leaching of metals. J. Biotechnol., 2001, 10, 191-224.

54. Vestola, E. A. et al., Acid bioleaching of solid waste materials from copper, steel and recycling industries. Hydrometallurgy, 2010, 103(1), 74-79.

55. Srichandan, H., Pathak, A., Singh, S., Blight, K., Kim, D. J. and Lee, S. W., Sequential leaching of metals from spent refinery catalyst in bioleaching-bioleaching and bioleaching-chemical leaching reactor: comparative study. Hydrometallurgy, 2014, 150, $130-143$ 
56. Bosecker, K., Bioleaching: metal solubilization by microorganisms. FEMS Microbiol. Rev., 1997, 20, 591-604.

57. Krebs, W., Brombacher, C., Bosshard, P. P., Bachofen, R. and Brandl, H., Microbial recovery of metals from solids. FEMS Microbiol. Rev., 1997, 20, 605-617.

58. Zhang, W. M. and Gu, S. F., Catalytic effect of activated carbon on bioleaching of low-grade primary copper sulfide ores. Trans. Nonferrous Met. Soc., 2007, 17, 1123-1127.

59. Barkay, T. and Schaefer, J., Metal and radionuclide bioremediation: issues, considerations and potentials. Curr. Opin. Microbiol., 2001, 4, 318-323.

60. Gavrilescu, M., Removal of heavy metals from the environment by biosorption. Eng. Life Sci., 2004, 4, 219-232.

61. Zhang, K., Xue, Y., Xu, H. and Yao, Y., Lead removal by phosphate solubilizing bacteria isolated from soil through biomineralization. Chemosphere, 2019, 224, 272-279.

62. Burbank, M. B., Weaver, T. J., Green, T. L., Williams, B. C. and Crawford, R. L., Precipitation of calcite by indigenous microorganisms to strengthen liquefiable soils. Geomicrobiol. J., 2011, 28, 301-312.

63. DeMuynck, W., De Belie, N. and Verstraete, W., Microbial carbonate precipitation in construction materials: a review. Ecol. Eng., 2010, 36, 99-111.

64. Gadd, G. M., Bahri-Esfahani, J., Li, Q., Rhee, Y. J., Wei, Z., Fomina, M. and Liang, X., Oxalate production by fungi: significance in geomycology, biodeterioration and bioremediation. Fungal Biol. Rev., 2014, 28, 36-55.

65. Yang, Y., Liu, X., Wang, J., Huang, Q., Xin, Y. and Xin, B., Screening bioleaching systems and operational conditions for optimal Ni recovery from dry electroplating sludge and exploration of the leaching mechanisms involved. Geomicrobiol. J., 2016, 33, 179-184.

66. Liang, K., Coghlan, C. J., Bell, S. G., Doonan, C. and Falcaro, P., Enzyme encapsulation in zeolitic imidazolate frameworks: a comparison between controlled co-precipitation and biomimetic mineralisation. Chem. Comm., 2016, 52, 473-476.

67. Liu, S. J. et al., The effect of several activated biochars on $\mathrm{Cd}$ immobilization and microbial community composition during in situ remediation of heavy metal contaminated sediment. Chemosphere, 2018, 208, 655-664.

68. Asha, S. and Vidyavathi, M., Cunninghamella-a microbial model for drug metabolism studies - a review. Biotechnol. Adv., 2009, 27, 16-29.

69. Pervaiz, I., Ahmad, S., Madni, M. A. and Khaliq, F. H., Microbial transformation: a tool for drug designing (review). Prikl. Biokhim. Mikrobiol., 2013, 49, 435-499.

70. Siddiquee, S., Rovina, K., Azad, S. A., Naher, L., Suryani, S. and Chaikaew, P., Heavy metal contaminants removal from wastewater using the potential filamentous fungi biomass: a review. J. Microbiol. Biochem. Technol., 2015, 7, 384-393.

71. Karigar, C. S. and Rao, S. S., Role of microbial enzymes in the bioremediation of pollutants - a review. Enzyme Res., 2011, 2011.

72. Nagvenkar, G. S. and Ramaiah, N., Arsenite tolerance and biotransformation potential in estuarine bacteria. J. Ecotoxicol., 2010, 19, 604-613.

73. Thatoi, H., Das, S., Mishra, J. and Prasad, B., Bacterial chromate reductase, a potential enzyme for bioremediation of hexavalent chromium: a review. J. Environ. Manage., 2014, 146, 383-399.

74. Lloyd, J. R. and Lovley, D. R., Microbial detoxification of metals and radionuclides. Curr. Opin. Biotechnol., 2001, 12, 248-253.

75. Ianieva, O. D., Mechanisms of bacteria resistance to heavy metals. Mikrobiol. Z, 2009, 71, 54-65.

76. Kumar, R., Singh, P., Dhir, B., Sharma, A. K. and Mehta, D., Potential of some fungal and bacterial species in bioremediation of heavy metals. J. Nucl. Phys. Mat. Sci. Rad. A, 2014, 1, 213223.
77. Bhati, T. et al., Assessment of bioremediation potential of Cellulosimicrobium sp. for treatment of multiple heavy metals. Microbiol. Biotechnol. Lett., 2019, 47, 269-277.

78. Teitzel, G. M. and Parsek, M. R., Heavy metal resistance of biofilm and planctonic Pseudomonas aeruginosa. Appl. Environ. Microbiol., 2003, 69, 2313-2320.

79. Grujić, S., Vasić, S., Radojević, I., Čomić, L. and Ostojić, A., Comparison of the Rhodotorula mucilaginosa biofilm and planktonic culture on heavy metal susceptibility and removal potential. Water Air Soil Pollut., 2017, 228, 73.

80. Brahmachari, P. V., Kishor, K., Ramadevi, R., Kumar, R., Rao, B. R. and Dubey, S. K., Isolation and characterization of mucous exopolysaccharides by Vibrio furnissi VB0S3. J. Microbiol. Biotechnol., 2007, 17, 47-51.

81. Kushwaha, A., Rani, R., Kumar, S., Thomas, T., David, A. A. and Ahmed, M., A new insight into adsorption and accumulation of high lead concentration by exopolymer and whole cells of leadresistance bacterium Acinetobacter junii $\mathrm{L}$. $\mathrm{Pb} 1$ isolated from coal mine dump. Environ. Sci. Pollut. Res., 2017, 24, 10652-10661.

82. Rasulov, B. A., Yili, A. and Aisa, H. A., Biosorption of metal ions by exopolysaccharide produced by Azotobacter chroococcum XU1. J. Environ. Prot., 2013, 4, 989-993.

83. Kazy, S. K., Sar, P., Sen, A. K. and D'Souza, S. F., Extracellular polysaccharides of a copper-sensitive and a copper-resistant Pseudomonas aeruginosa strain: synthesis, chemical nature and copper binding. World J. Microbiol. Biotechnol., 2002, 18, 583-588.

84. Nies, D. H., Nies, A., Chu, L. and Silver, S., Expression and nucleotide sequence of a plasmid-determined divalent cation efflux system from Alcaligenes eutrophus. Proc. Natl. Acad. Sci. USA, 1989, 86, 7351-7355.

85. Rosen, B. P., Biochemistry of arsenic detoxification. FEBS Lett., $2002, \mathbf{5 2 9}, 86-92$.

86. Franke, S., Grass, G., Rensing, C. and Nies, D. H., Molecular analysis of the copper transporting efflux system CusCFBA of Escherichia coli. J. Bacteriol., 2003, 185, 3804-3812.

87. Ontañon, O. M., Fernandez, M., Agostini, E. and González, P. S., Identification of the main mechanisms involved in the tolerance and bioremediation of $\mathrm{Cr}(\mathrm{VI})$ by Bacillus sp. SFC 500-1E. Environ. Sci. Pollut. Res., 2018, 25, 16111-16120.

88. Vats, N. and Lee, S. F., Characterization of copper transport operon, copYAZ, from Streptococcus mutans. Microbiology, 2001, 147, 653-662.

89. Gutiérrez-Corona, J. F., Romo-Rodríguez, P., Santos-Escobar, F., EspinoSaldaña, A. E. and Hernández-Escoto, H., Microbial interactions with chromium: basic biological processes and applications in environmental biotechnology. World J. Microbiol. Biotechnol., 2016, 32, 191.

90. Mukhopadhyay, R., Rosen, B. P., Phung, L. T. and Silver, S., Microbial arsenic: from geocycles to genes and enzymes. FEMS Micobiol. Rev., 2002, 26, 311-325.

91. Baaziz, H. et al., ChrASO, the chromate efflux pump of Shewanella oneidensis, improves chromate survival and reduction. PLoS ONE, 2017, 12, 1-15.

92. Igiri, B. E., Okoduwa, S. I. R., Idoko, G. O., Akabuogu, E. P., Adeyi, A. O. and Ejiogu, I. E., Toxicity and bioremediation of heavy metals contaminated ecosystem from tannery wastewater: a review. J. Toxicol., 2018, 16, 2568038.

93. Cha, J. S. and Cooksey, D. A., Copper resistance in Pseudomonas syringae mediated by periplasmic and outer membrane proteins. Microbiology, 1991, 88, 8915-8919.

94. Gilotra, U. and Srivastava, S., Plasmid-encoded sequestration of copper by Pseudomonas pickettii strain US321. Curr. Microbiol., 1997, 34, 378-381.

95. Sharma, P. K., Balkwill, D. L., Frenkel, A. and Vairavamurthy, M. A., A new Klebsiella planticola strain (Cd-1) grows anaerobically at high cadmium concentrations and precipitates cadmium sulfide. Appl. Environ. Microbiol., 2000, 66, 3083-3087. 
96. Saxena, D. and Srivastava, S., Carbon source-starvation-induced precipitation of copper by Pseudomonas putida strain S4. World J. Microbiol. Biotechnol., 1998, 14, 921-923.

97. Yin, K., Wang, Q., Lv, M. and Chen, L., Microorganism remediation strategies towards heavy metals. Chem. Eng. J., 2019, 360, 1553-1563.

98. Pinto, E., Sigaud-Kutner, T. C. S., Leitao, M. A. S., Okamoto, O K., Morse, D. and Colepicolo, P., Heavy metal-induced oxidative stress in algae. J. Phycol., 2003, 39, 1008-1018.

99. Richards, R. I., Heguy, A. and Karin, M., Structural and functional analysis of the human metallothionein-IA gene: differential induction by metal ions and glucocorticoids. Cell, 1984, 37, 263-272.

100. Ybarra, G. R. and Webb, R., Effects of divalent metal cations and resistance mechanisms of the cyanobacterium Synechococcus sp. strain PCC 7942. J. Hazard. Mater., 1999, 2, 1-9.

101. Blindauer, C. A., Harrison, M. D., Parkinson, J. A., Robinson, N. J. and Sadler, P. J., Isostructural replacement of zinc by cadmium in bacterial metallothionein. Met. Ions Biol. Syst., 2008, 10, 167 173.

102. Balzano, S., Sardo, A., Blasio, M., Chahine, T. B., Dell'Anno, F., Sansone, C. and Brunet, C., Microalgae metallothioneins and phytochelatins and their potential use in bioremediation. Front. Microbiol., 2020, 11, 517.

103. Clemens, S. and Simm, C., Schizosaccharomyces pombe as a model for metal homeostasis in plant cells: the phytochelatindependent pathway is the main cadmium detoxification mechanism. New Phytol., 2003, 159, 323-330.

104. Talukdar, D. et al., Evaluation of novel indigenous fungal consortium for enhanced bioremediation of heavy metals from contaminated sites. Environ. Technol. Innov., 2020, 20, 101050.

105. Barkay, T., Miller, S. M. and Summers, A. O., Bacterial mercury resistance from atoms to ecosystems. FEMS Microbiol. Rev., 2003, 27, 355-384

106. Smirnova, G. F., Distribution of bacteria resistant to oxygencontaining anions-xenobiotics. Mikrobiol. Z., 2005, 67, 11-18.

107. Joshi, N. J., Coker, V. S., Sadhukhan, J., Safarik, I., Bagshaw, H. and Lloyd, J. R., Microbial reduction of natural Fe(III) minerals: toward the sustainable production of functional magnetic nanoparticles. Front. Environ. Sci., 2018, 6, 127.

108. Ma, L., Xu, J., Chen, N., Li, M. and Feng, C., Microbial reduction fate of chromium $(\mathrm{Cr})$ in aqueous solution by mixed bacterial consortium. Ecotoxicol. Environ. Saf., 2019, 170, 763-770.

109. Summers, A. O. and Silver, S., Mercury resistance in a plasmidbearing strain of Escherichia coli. J. Bacteriol., 1972, 112, 12281236

110. Mergeay, M. et al., Alcaligenes eutrophus $\mathrm{CH} 34$ is a facultative chemolithotroph with plasmid-bourne resistance to heavy metals. J. Bacteriol., 1985, 162, 328-334.

111. Nies, D. H., Microbial heavy-metal resistance. Appl. Microbiol. Biotechnol., 1999, 51, 730-750.

112. Cooksey, D. A., Copper uptake and resistance in bacteria. Mol. Microbiol., 1993, 7, 1-5.

113. Beard, S. J., Hughes, M. N. and Poole, R. K., Inhibition of the cytochrome $b d$-terminated NADH oxidase system in Escherichia coli K-12 by divalent metal cations. FEMS Microbiol. Lett., 1995 , 131, 205-210.

114. Bruins, M. R., Kapil, S. and Oehme, F. W., Microbial resistance to metals in the environment. Ecotoxicol. Environ. Saf., 2000, 45 198-207

115. Cervantes, C. and Campos-Garcia, J., Reduction and efflux of chromate by bacteria. In Molecular Microbiology of Heavy Metals, Springer-Verlag, Berlin, Germany, 2007, pp. 407-419.

116. Silver, S., Bacterial resistances to toxic metal ions: a review. Gene, 1996, 179, 9-19.

117. Ji, G. and Silver, S., Bacterial resistance mechanisms for heavy metals of environmental concern. J. Ind. Microbiol., 1995, 14, $61-75$.
118. Hobman, J. L. and Brown, N. L., Overexpression of MerT, the mercuric ion transport protein of transposon Tn501, and genetic selection of mercury hypersensitivity mutations. Mol. Gen. Genet., 1996, 250, 129-134.

119. Schiering, N., Kabsch, W., Moore, M. J., Distefano, M. D., Walsh, C. T. and Pai, E. F., Structure of the detoxification catalyst mercuric ion reductase from Bacillus sp. strain RC607. Nature, 1991, 352, 168-172.

120. Silver, S. and Phung, L. T., Bacterial heavy metal resistance: new surprises. Annu. Rev Microbiol., 1996, 50, 753-789.

121. Chang, J., Shi, Y., Si. J., Chan, Q., Dong, J. and Chen, J., The bioremediation potentials and mercury(II)-resistant mechanisms of a novel fungus Penicillium spp. DC-F11 isolated from contaminated soil. J. Hazard. Mater., 2020, 396, 122638.

122. Ji, G. and Silver, S., Reduction of arsenate to arsenite by the ArsC protein of the arsenic resistance operon of Staphylococcus aureus plasmid pi258. Proc. Natl. Acad. Sci. USA, 1992, 89, 94749478.

123. Rosenstein, R., Peschel, A., Wieland, B. and Gotz, F., Expression and regulation of the antimonite, arsenite, and arsenate resistance operon of Staphylococcus xylosus plasmid pSX267. J. Bacteriol., 1992, 174, 3676-3683.

124. Wu, J. and Rosen, B. P., The $\operatorname{ars} D$ gene encodes a second transacting regulatory protein of the plasmid-encoded arsenical resistance operon. Mol. Microbiol., 1993, 8, 615-623.

125. Nies, D. H. and Silver, S., Ion efflux systems involved in bacterial metal resistances. J. Ind. Microbiol., 1995, 14, 186-199.

126. Ji, G. Y., Garber, E. A. E., Armes, L. G., Chen, C. M., Fuchs, J. A. and Silver, S., Arsenate reductase of Staphylococcus aureus plasmid pI258. Biochem. J., 1994, 33, 7294-7299.

127. Wu, X., Xia, X., Wang, D., Zhou, Z. and Wang, G., Gene function and expression regulation of RuvRCAB in bacterial $\mathrm{Cr}(\mathrm{VI})$, $\mathrm{As}(\mathrm{III}), \mathrm{Sb}(\mathrm{III})$, and $\mathrm{Cd}(\mathrm{II})$ resistance. Appl. Microbiol. Biotechnol., 2019, 103, 2701-2713.

128. Cánovas, D., Cases, I. and De Lorenzo, V., Heavy metal tolerance and metal homeostasis in Pseudomonas putida as revealed by complete genome analysis. Environ. Microbiol., 2003, 5, 1242 1256

129. Nies, D. H. and Silver, S., Metal ion uptake by a plasmid-free metal-sensitive Alcaligenes eutrophus strain. J. Biol. Chem., 1989, 171, 4073-4075.

130. Liu, X. F., Supek, F., Nelson, N. and Culotta, V. C., Negative control of heavy metal uptake by the Saccharomyces cerevisiae BSD2 gene. J. Biol. Chem., 1997, 272, 11763-11769.

131. Silver, S. and Walderhaug, M., Gene regulation of plasmid and chromosome-determined inorganic ion transport in bacteria Microbiol. Rev., 1992, 56, 195-228.

132. Silver, S., Nucifora, G., Chu, L. and Misra, T. K., Bacterial resistance ATPases: primary pumps for exporting toxic cations and anions. Trends Biochem. Sci., 1989, 14, 76-80.

133. Silver, S. and Ji, G., Newer systems for bacterial resistances to toxic heavy metals. Environ. Health Perspect., 1994, 102, 107113

134. Schmidt, T. and Schiefner, A., Combined nickel-cobalt-cadmium resistance encoded by ncc locus of Alcaligenes xylosoxidans $31 \mathrm{~A}$. J. Bacteriol., 1994, 176, 7045-7054.

135. Nies, D. H., $C z c R$ and $C z c D$ gene products affecting regulation of resistance to cobalt, zinc, and cadmium (czc system) in Alcaligenes eutrophus. J. Bacteriol., 1992, 174, 8102-8110.

136. Li, J., Liu, S. and Rosen, B. P., Interaction of ATP binding sites in the ArsA ATPase, the catalytic subunit of the Ars pump. J. Biol. Chem., 1996, 271, 247-252.

137. Li, L. T. and Kaplan, J., Characterization of two homologous yeast genes that encode mitochondrial iron transporters. J. Biol. Chem., 1997, 272, 485-493.

138. Olafson, R. W., Abel, K. and Sim, R. G., Prokaryotic metallothionein, preliminary characterization of a blue green alga heavy 
metal-binding protein. Biochem. Biophys. Res. Commun., 1979, 89, 36-42.

139. Huckle, J., Morby, A. P., Turner, J. S. and Robinson, N. J., Isolation of prokaryotic metallothionein locus and analysis of transcriptional control by trace metal ions. Mol. Microbiol., 1993, 7, 177-187.

140. Borremans, B., Hobman, J. L., Provoost, A., Brown, N. L. and van der Lelie, D., Cloning and functional analysis of the pbr lead resistance determinant of Ralstonia metallidurans $\mathrm{CH} 34$. J. Bacteriol., 2001, 183, 5651-5658.

141. Tolbatov, L., Re, N., Coletti, C. and Marrone, A., Determinants of the lead(II) affinity in pbrR protein: a computational study. Inorg. Chem., 2020, 59, 790-800.

142. Hlihor, R. M., Figueiredo, H., Tavares, T. and Gavrilescu, M., Biosorption potential of dead and living Arthrobacter viscosus biomass in the removal of $\mathrm{Cr}(\mathrm{VI})$ : batch and column studies. Process Saf. Environ. Prot., 2017, 18, 44-56.

143. Babak, L., Šupinova, P., Zichova, M., Burdychova, R. and Vitova, E., Biosorption of $\mathrm{Cu}, \mathrm{Zn}$ and $\mathrm{Pb}$ by thermophilic bacteria-effect of biomass concentration on biosorption capacity. Acta Univ. Agric. Silvicult. Mend. Brunensis., 2012, 5, 9-17.

144. Rani, M. J., Hemambika, B., Hemapriya, J. and Kannan, R. V., Comparative assessment of heavy metal removal by immobilized and dead bacterial cells. A biosorption approach. Afr. J. Environ. Sci. Tech., 2010, 4, 077-083.

145. Jiang, J., Liu, H., Li, Q., Gao, N., Yao, Y. and Xu, H., Combined remediation of $\mathrm{Cd}$ phenanthrene co-contaminated soil by Pleurotus cornucopiae and Bacillus thuringiensis FQ1 and the antioxidant responses in Pleurotus cornucopiae. Ecotoxicol. Environ. Saf., 2015, 120, 386-393.

146. Kang, C. H., Kwon, Y. J. and So, J. S., Bioremediation of heavy metals by using bacterial mixtures. Ecol. Eng., 2016, 89, 64-69.

147. Boddu, S., Alugunulla, V. N., Dulla, J. B., Chavali, M., Pilli, R. R. and Khan, A. A., Estimation of biosorption characteristics of chromium (VI) from aqueous and real tannery effluents by treated T. vulgaris: experimental assessment and statistical modelling. Int. J. Environ. An. Ch., 2020, 1-20.

148. Khadivinia, E. et al., Cadmium biosorption by a glyphosatedegrading bacterium, a novel biosorbent isolated from pesticidecontaminated agricultural soils. J. Ind. Eng. Chem., 2014, 20, 4304-4310

149. Yin, K., Lv, M., Wang, Q., Wu, Y., Liao, C., Zhang, W. and Chen, L., Simultaneous bioremediation and biodetection of mercury ion through surface display of carboxylesterase E2 from Pseudomonas aeruginosa PA1. Water Res., 2016, 103, 383-390.

150. Kumari, S. and Das, S., Expression of metallothionein encoding gene bmtA in biofilm-forming marine bacterium Pseudomonas aeruginosa N6P6 and understanding its involvement in $\mathrm{Pb}(\mathrm{II})$ resistance and bioremediation. ESPR, 2019, 26, 28763-28774.

151. Azzam, A. M. and Tawfik, A., Removal of heavy metals using bacterial bio-flocculants of Bacillus sp. and Pseudomonas sp. J. Environ. Eng. Landsc. Manage., 2015, 23, 288-294.

152. Nanda, M., Sharma, D. and Kumar, A., Isolation and characterization of bacteria resistant to heavy metals cadmium (Cd), arsenic (As), mercury $(\mathrm{Hg})$ from industrial effluent. Global. J. Appl. Environ. Sci., 2011, 2, 127-132.

153. Magnin, J. P., Gondrexon, N. and Willison, J. C., Zinc biosorption by the purple nonsulfur bacterium Rhodobacter capsulatus. Can. J. Microbiol., 2014, 60, 829-837.

154. Jalilvand, N., Akhgar, A., Alikhani, H. A., Rahmani, H. A. and Rejali, F., Removal of heavy metals zinc, lead, and cadmium by biomineralization of urease-producing bacteria isolated from Iranian mine calcareous soils. J. Soil Sci. Plant Nutr., 2020, 20, 206-219.

155. Samarth, D. P., Chandekar, C. J. and Bhadekar, R. K., Biosorption of heavy metals from aqueous solution using Bacillus licheniformis Int. J. Pure Appl. Sci. Technol., 2012, 10, 12-19.
156. Nanda, M., Sharma, D. and Kumar, A., Removal of heavy metals from industrial effluent using Bacteria. Int. J. Environ. Sci., 2011, 2, 781-787.

157. Chen, S., Yin, H., Ye, J., Peng, H., Liu, Z., Dang, Z. and Chang, J., Influence of coexisted benzo[a]pyrene and copper on the cellular characteristics of Stenotrophomonas maltophilia during biodegradation and transformation. Bioresour Technol., 2014, 158, 181-187.

158. Iram, S. and Abrar, S., Biosorption of copper and lead by heavy metal resistant fungal isolates. Int. J. Sci. Res. Publ., 2015, 5, $1-5$.

159. Tekova, K., Todorova, D., Dencheva, V. and Ganeva, S., Biosorption of copper(II) and cadmium(II) from aqueous solutions by free and immobilized biomass of Aspergillus niger. Bioresour. Technol., 2010, 101, 1727-1731.

160. Dhal, B. and Pandey, B. D., Mechanism elucidation and adsorbent characterization for removal of $\mathrm{Cr}(\mathrm{VI})$ by native fungal adsorbent. Sustain. Environ. Res., 2018, 28, 289-297.

161. Ma, X. K., Ling, Wu, L. and Fam, H., Heavy metal ions affecting the removal of polycyclic aromatic hydrocarbons by fungi with heavy-metal resistance. Appl. Microbiol. Biotechnol., 2014, 98, 9817-9827.

162. Ramrakhiani, L., Majumder, R. and Khowala, S., Removal of hexavalent chromium by heat inactivated fungal biomass of Termitomyces clypeatus: surface characterization and mechanism of biosorption. Chem. Eng. J., 2011, 171, 1060-1068.

163. Bazrafshan, E., Zarei, A. A. and Mostafapour, F. K., Biosorption of cadmium from aqueous solutions by Trichoderma fungus: kinetic, thermodynamic and equilibrium study. Desalin. Water Treat., 2016, 57, 14598-14608.

164. Amirnia, S., Ray, M. B. and Margaritis, A., Heavy metals removal from aqueous solutions using Saccharomyces cerevisiae in a novel continuous bioreactor-biosorption system. Chem. Eng. J., 2015, 264, 863-872.

165. Saavedra, R., Muñoz, R., Taboada, M. E., Vega, M. and Bolado, S., Comparative uptake study of arsenic, boron, copper, manganese and zinc from water by different green microalgae. Bioresour. Technol., 2018, 263, 49-57.

166. Solisio, C., Al Arni, S. and Converti, A., Adsorption of inorganic mercury from aqueous solutions onto dry biomass of Chlorella vulgaris: kinetic and isotherm study. Environ. Technol., 2019, 40, 664-672.

167. Christoforidis, A., Orfanidis, S., Papageorgiou, S., Lazaridou, A., Favvas, E. and Mitropoulos, A. C., Study of $\mathrm{Cu}(\mathrm{II})$ removal by Cystoseira crinitophylla biomass in batch and continuous flow biosorption. Chem. Eng. J., 2015, 277, 334-340.

168. Demey, H., Vincent, T. and Guibal, E., A novel algal-based sorbent for heavy metal removal. Chem. Eng. J., 2018, 332, 582-595.

169. Barquilha, C., Cossich, E., Tavares, C. and Silva, E., Biosorption of nickel (II) and copper (II) ions in batch and fixed-bed columns by free and immobilized marine algae Sargassum sp. J. Clean. Prod., 2017, 150, 58-64.

170. Cardoso, S. C., Costa, C. S. D., Nishikawa, E., da Silva, M. G. C., and Vieira, M. G. A., Biosorption of toxic metals using the alginate extraction residue from the brown algae Sargassum filipendula as a natural ion-exchanger. J. Cleaner Prod., 2017, 165, 491-449.

171. Ungureanu, G., Santos, S., Boaventura, R. and Botelho, C., Biosorption of antimony by brown algae $S$. muticum and $A$. nodosum. Environ. Eng. Manage. J., 2015, 14, 455-463.

172. Lee, Y. C. and Chang, S. P., The biosorption of heavy metals from aqueous solution by Spirogyra and Cladophora filamentous macroalgae. Bioresour. Technol., 2011, 102, 5297-5304.

Received 25 July 2019; revised accepted 20 November 2020

doi: $10.18520 / \mathrm{cs} / \mathrm{v} 120 / \mathrm{i} 6 / 1013-1025$ 